\title{
PENINGKATAN KETERAMPILAN MEMBACA PUISI SISWA KELAS IV DENGAN MODEL DEMONSTRASI DIDUKUNG MEDIA VIDEO PEMBELAJARAN DI SDN 1 SUMBERSARI KOTA MALANG
}

\author{
Yolanda Dana Kumala Sari ${ }^{1}$, Lise Chamisijatin ${ }^{2}$, dan Budi Santoso ${ }^{3}$ \\ PPG PGSD FKIP Universitas Muhammadiyah Malang ${ }^{1,2}$, SDN Sumbersari 1 Malang $^{3}$ \\ Email: andhayola@gmail.com ${ }^{1}$; lisechamisijatin@gmail.com ${ }^{2}$; hafis_budi@yahoo.com ${ }^{3}$
}

\begin{tabular}{|c|c|}
\hline Info Artikel & Abstract \\
\hline $\begin{array}{l}\text { Sejarah Artikel: } \\
\text { Diterima 5 April } 2019 \\
\text { Direvisi } 20 \text { Mei } 2019 \\
\text { Disetujui } 30 \text { Mei } 2019\end{array}$ & $\begin{array}{l}\text { The purpose of this study is to improve poetry reading skill of } 4^{\text {th }} \text { grade students at SDN } \\
\text { Sumbersari } 1 \text { in Malang City, to know the activities of the teacher and students. This type } \\
\text { of this research is classroom action research. This classroom action research model uses } \\
\text { the Kemmis \& Mc Taggart model which consist of four steps or stages in conducting } \\
\text { classroom action research, namely: planning, action, observation, and reflection. The } \\
\text { result of the study show an increasing activity of the teacher and students. The result of this }\end{array}$ \\
\hline $\begin{array}{l}\text { Keywords: } \\
\text { Demonstration, Learning } \\
\text { Video, Poetry Reading }\end{array}$ & $\begin{array}{l}\text { study are flows. (1) Pre-action, from } 25 \text { students, only } 5 \text { students or } 20 \% \text { of the total } \\
\text { students are able to read poetry well and correctly, while } 20 \text { students or } 80 \% \text { of students } \\
\text { experience difficulty in reading poetry with an average poetry reading skill of } 54.56 \% \text {. (2) } \\
\text { Cycle I, the percentage of teacher activity reached } 83 \% \text { with very good predicate, the } \\
\text { percentage of teacher activity reached } 83 \% \text { with very good predicate, the percentage of } \\
\text { student activity was } 83 \% \text { with very good predicate, and classical learning completeness } \\
\text { was } 78.8 \% \text { (3) Cycle II, the percentage of teacher activity reached } 86 \% \text { with very good } \\
\text { predicate, the percentage of students is } 87 \% \text { with a very good predicate, and the } \\
\text { percentage of classical learning completeness is } 96 \% \text {. }\end{array}$ \\
\hline
\end{tabular}

\begin{abstract}
Abstrak
Tujuan penelitian ini adalah untuk meningkatkan keterampilan membaca puisi siswa kelas IV SDN Sumbersari Kota Malang, mengetahui aktivitas guru, dan siswa. Jenis penelitian ini adalah penelitian tindakan kelas. Model penelitian tindakan kelas ini menggunakan model Kemmis \& Mc Taggart yang terdiri atas empat langkah atau tahapan dalam pelaksanaan penelitian tindakan kelas yakni: perencanaan, tindakan, observasi, dan refleksi. Hasil penelitian menunjukkan adanya peningkatan aktivitas guru dan siswa. Hasil penelitian ini sebagai berikut. (1) Pratindakan, dari 25 siswa, hanya 5 siswa atau $20 \%$ dari jumlah keseluruhan siswa yang mampu membaca puisi dengan baik dan benar, sedangkan 20 siswa atau $80 \%$ siswa mengalami kesulitan dalam membaca puisi dengan rata-rata keterampilan membaca puisi sebesar $54,56 \%$. (2) Siklus I, persentase aktivitas guru mencapai $83 \%$ dengan predikat sangat baik, persentase aktivitas siswa sebesar $83 \%$ dengan predikat sangat baik,dan ketuntasan belajar klasikal sebesar 78,8\% (3) Siklus II, persentase aktivitas guru mencapai $86 \%$ dengan predikat sangat baik, persentase aktivitas siswa sebesar $87 \%$ dengan predikat sangat baik, dan persentase ketuntasan belajar klasikal sebesar $96 \%$.
\end{abstract}

(C) 2019 Universitas Muria Kudus 


\section{PENDAHULUAN}

Bahasa merupakan alat komunikasi sosial yang berupa sistem simbol bunyi yang dihasilkan dari alat ucap manusia. Manusia sebagai makhluk sosial membutuhkan sarana untuk berinteraksi dengan manusia lainnya di masyarakat, sehingga manusia membutuhkan bahasa. Bahasa merupakan struktur dan makna yang bebas dari penggunanya sebagai yang menyimpulkan suatu tujuan. Hal itu berarti makna bahasa bergantung kepada penggunanya dan sesuai dengan tujuannya.

Selain sebagai alat komunikasi sosial, salah satu fungsi bahasa yakni sebagai ekspresi diri. Bahasa memiliki fungsi ekspresi diri berarti bahwa bahasa berfungsi untuk menyalurkan perasaan, gagasan, dan emosi pengguna bahasa. Bahasa sebagai alat untuk mengekspresikan diri dapat menjadi media untuk menyatakan keberadaan (eksistensi) diri, membebaskan diri dari tekanan emosi, dan untuk menarik perhatian orang lain. Fungsi bahasa sebagai ekspresi diri dapat dimaksimalkan melalui apresiasi sastra anak.

Apresiasi sastra memberikan manfaat bagi anak yaknibelajar memahami maksud yang disampaikan orang lain dan merasakan emosi orang lain sehingga hal tersebut dapat membekali diri anak dalam berinteraksi dengan orang lain. Ada lima manfaat yang dapat diperoleh ketika mengapresiasi sastra sastra, yakni: (1) estetis, artinya ada keindahan yang melekat pada sastra; (2) pendidikan, yaitu memberi berbagai informasi tentang proses pengubahan sikap dan tata laku seseorang atau kelompok orang dalam usaha mendewasakan manusia melalui pengajaran dan latihan; (3) kepekaan batin atau sosial, yaitu dalam mengapresiasi sastra akan selalu mengasah batin agar mudah tersentuh oleh hal-hal yang bersifat batiniah ataupun sosial; (4) menambah wawasan, artinya memberi tambahan informasi, pengetahuan, pengalaman hidup, dan pandangan-pandangan tentang kehidupan; (5) pengembangan kejiwaan atau kepribadian yaitu mampu menghaluskan budi pekerti seorang apresiator (Santosa, 2008).

Salah satu pembelajaran apresiasi sastra pada sekolah dasar yaitu membaca puisi. Membaca puisi termasuk kegiatan membaca nyaring untuk kepentingan seni. Ada beberapa hal yang harus diperhatikan ketika membaca puisi yakni; (1) lafal; (2) intonasi; dan (3) ekspresi. Tujuannya agar dapat membaca puisi dengan penuh perasaan sesuai dengan pesan dari puisi itu (Warsidi dan Farika, 2008).

Berdasarkan hasil observasi di lapanganpada 22 Januari 2019 guru telah melakukan pembelajaran sastra lewat demonstrasi yaitu dengan meminta peserta didik untuk memeragakan pembacaan puisi di depan kelas. Akan tetapi, dikarenakan kurangnya pengetahuan peserta didik tentang membaca puisi yang baik dan benar serta keterbatasan guru yang tidak dapat memberikan contoh membaca puisi yang baik dan benar. Hal tersebut menyebabkan $80 \%$ peserta didik tidak mencapai batas nilai minimal yang harus dicapai dalam membaca puisi. Sebanyak $80 \%$ peserta didik tersebut tidak mampu mencapai aspek meliputi (1) jeda, (2) intonasi, (3) ekspresi, dan (4) pelafalan. Peserta didik hanya membaca puisi tersebut seperti membaca bacaan pada umumnya tanpa disertai intonasi, jeda, dan ekspresi. Peserta didik juga masih membaca teks puisi mereka tanpa penghayatan.

Handayani (2011) menyatakan "Sebagian besar proses belajar yang dialami manusia dibentuk melalui melihat sesuatu atau contoh. Dengan kata lain, seseorang dapat belajar melalui pengamatan dan meniru perilaku orang lain". Agar pembelajaran sastra terutama membaca puisi bermakna dan dapat menstimulus kreativitas peserta didik maka dapat menggunakan media video pembelajaran. Video tersebut juga dapat membantu kekurangan guru dalam memberikan contoh pembacaan puisi yang baik dan benar. Selain itu, media video pembelajaran dapat memberikan referensi kepada siswa bagaimana cara membaca puisi yang baik dan benar dengan mengamati, melihat, dan mendengar video, siswa dapat mengetahui ekspresi dan gerak tubuh melalui pengamatan, jeda dan intonasi melalui pendengaran. Hal ini sejalan dengan pendapat Hanif, et al (2018: 78) bahwa "Media video pembacaan puisi dapat menambah antusias siswa dalam pembelajaran membaca puisi".

Selain penggunaan media video pembelajaran, guru juga perlu menerapkan model pembelajaran untuk melaksanakan pembelajaran. Model pembelajaran yang dapat diterapkan pada siswa kelas IV SDN Sumbersari 1,yakni Model Demonstrasi. Melalui model tersebut siswa dapat mendemostrasikan langsung pembacaan puisi yang baik dan benar setelah menonton video pembelajaran.

Beberapa penelitian terdahulu yang relevan dengan penelitian ini, yakni penelitian yang dilakukan oleh Dwi (2016) menunjukkan terjadi peningkatan rata-rata minat belajar siswa dengan menggunakan media audio visual dari 49,4 (minat sedang) meningkat menjadi 53 (minat tinggi) pada siklus I dan di akhir siklus II mengalami peningkatan menjadi 54,1 (minat tinggi). Selain itu, keterampilan membaca puisi juga mengalami peningkatan dari kenaikan rata- 
rata pada siklus I yang meningkat menjadi 72,6 dari kondisi awal 67,6 dan di akhir siklus I menjadi 78,6.

Penelitian Hartanti (2015) menunjukkan terjadi peningkatan proses belajar membaca puisi, yakni nilai rata-rata pada siklus I mencapai 65 dengan ketuntasan belajar kelas 33\%, siklus II nilai rata-rata meningkat menjadi 84 dengan ketuntasan belajar kelas $83 \%$, dan aktivitas belajar murid meningkat dari kualifikasi cukup pada siklus I menjadi kualifikasi baik pada siklus II.

Berdasarkan penelitian-penelitian terdahulu dapat disimpulkan bahwa penggunaan media video dapat meningkatkan minat belajar dan keterampilan membaca puisi siswa. Peningkatan hasil belajar membaca puisi juga terjadi pada pembelajaran dengan menggunakan metode demonstrasi. Berdasarkan hal tersebut, maka peneliti mengambil judul penelitian "Peningkatan Keterampilan Membaca Puisi Siswa Kelas IV dengan Model Demonstrasi didukung Media Video Pembelajaran di SDN 1 Sumbersari Kota Malang".

\section{METODE PENELITIAN}

Penelitian dilaksanakan di kelas IV SDN Sumbersari 1 Kota Malang pada 28 dan 30 Januari 2019. Subjek penelitian ini adalah guru dan siswa kelas IV SDN Sumbersari 1 Kota Malang. Jumlah siswa 25 orang, terdiri atas 14 siswa laki-laki dan 11 siswa perempuan.

Jenis penelitian yang digunakan dalam penelitian ini, yakni penelitian tindakan kelas (PTK) yang bertujuan untuk meningkatkan kualitas proses dan hasil pembelajaran di kelas yang dilakukan secara bersiklus.

Penelitian Tindakan Kelas ini menggunakan model Kemmis \& Mc Taggart yang terdiri atas empat langkah atau tahapan dalam pelaksanaan penelitian tindakan kelas,yakni: perencanaan, tindakan, observasi, dan refleksi. Ada beberapa tahapan dan proses yang perlu dilaksanakan sebelum, selama, ataupun sesudah penelitian. Sesuai dengan jenis penelitian tindakan, penelitian ini menggunakan prosedur kerja yang dipandang sebagai suatu siklus spiral dari perencanaan, tindakan, observasi dan refleksi. Prosedur penelitian tindakan kelas yang diterapkan dalam penelitian ini diuraikan sebagai berikut.

\section{Tahap Pratindakan}

Pada tahap pratindakan, peneliti bertindak sebagai observer. Peneliti melihat dan mengamati jalannya pembelajaran yang dilaksanakan oleh guru kelas IV pada pembelajaran membaca puisi. Pengamatan peneliti meliputi pelaksanaan pembelajaran, model, media maupun strategi pembelajaran yang digunakan oleh guru, dan seluruh kegiatan siswa selama pembelajaran. Setelah pratindakan, seluruh hasil pembelajaran nantinya dianalisis dan digunakan sebagai landasan dalam penelitian selanjutnya yang dilaksanakan oleh peneliti.

Kegiatan yang dilaksanakan peneliti pada pratindakan adalah mengamati kegiatan pembelajaran membaca puisi yang dilaksanakan guru kelas IV. Dari observasi yang dilaksanakan, peneliti memperoleh dan mengumpulkan data dari permasalahan yang dihadapi di dalam kelas termasuk permasalahan guru dan siswa sehingga peneliti mampu melaksanakan refleksi dari permasalahan yang muncul. Hasil refleksi dari observasi yang akan dilaksanakan didiskusikan bersama guru kelas IV untuk menentukan kegiatan pembelajaran yang akan dilaksanakan pada siklus I. Selain itu, peneliti juga mendiskusikan tentang instrumen penilaian yang akan digunakan untuk mengukur kemampuan siswa pada pelaksanaan pembelajaran siklus I.

\section{Tahap Tindakan}

\section{a. Siklus I}

Siklus I direncanakan sebanyak 1 kali pertemuan dengan alokasi waktu 3x 35 menit. Selama penelitian nanti, peneliti bertindak sebagai guru, dibantu oleh guru kelas IV yang bertindak sebagai observer (pengamat).

\section{1) Perencanaan}

Hal-hal

yang direncanakan pada siklus I, yakni memilih materi yang akan dipelajari siswa, merancang RPP berdasarkan rekomendasi dan refleksi pada saat pratindakan, menyiapkan media, menyiapkan instrumen berupa LKPD, LKK, lembar pengamatan, tes akhir, kamera sebagai alat dokumentasi, dan melakukan kolaborasi dengan guru kelas sebagai pengamat.

\section{2) Pelaksanaan}

Pelaksanaan tindakan pada siklus I direncanakan sebanyak 1 kali pertemuan, dengan durasi waktu $3 \times 35$ menit. Pertemuan akan dilaksanakan berdasarkan RPP yang sudah dibuat peneliti, yaitu RPP dengan model demonstrasi didukung media video pembelajaran. 
Kegiatan yang dilakukan pada tahap ini adalah melaksanakan langkah-langkah pembelajaran model Demontrasi dan media video pembelajaran yang tercantum dalam rencana pelaksanaan pembelajaran yang telah disusun sebelumnya. Pelaksanaan tindakan dimulai dengan kegiatan pendahuluan berupa salam dan doa, apersepsi, penyampaian tujuan pembelajaran dan pemberian motivasi.

Pada kegiatan inti, guru melaksanakan pembelajaran sesuai sintaks model Demontrasi dan penggunaan media video pembelajaran. Pada kegiatan ini siswa mengamati peragaan guru membaca puisi, kemudian siswa mengamati video pembelajaran yang berupa video pembacaan puisi. Setelah pengamatan video guru meminta pendapat kepada siswa tentang pembacaan puisi pada video. Guru memberikan penguatan dan menjelaskan cara membaca puisi yang baik dan benar. Setelah itu, siswa membacakan puisi yang telah dibuat sebelumnya secara bergantian di depan kelas.

Pada kegiatan akhir, guru menjelaskan kembali materi yang belum dipahami siswa. Siswa dengan bimbingan guru menarik simpulan materi yang telah dipelajari. Sebagai evaluasi akhir, siswa diberikan tes akhir untuk mengetahui sejauh mana siswa memahami materi yang diperolehnya. Kemudian guru melakukan refleksi dengan menyampaikan kesan-kesan belajar menggunakan media mika transparan, lalu mengakhiri pembelajaran dengan salam dan doa.

3) Pengamatan

Pada tahap ini yang dilakukan mengamati peristiwa pembelajaran yang sesuai dengan fokus masalah, terutama perilaku siswa yang sedang mengikuti kegiatan pembelajaran. Memantau kegiatan siswa, mengamati keaktivan dan kreativitas siswa, melakukan dokumentasi, serta mencatat halhal penting yang sedang terjadi selama pembelajaran.

\section{4) Refleksi}

Pada tahap ini yang akan dilakukan adalah menelaah hasil observasi, mencatat kelemahankelemahan selama pelaksanaan pembelajaran, dan menentukan tindakan yang perlu dilakukan untuk dijadikan bahan perencanaan ulang pada siklus berikutnya sampai tujuan PTK tercapai. Selain itu peneliti juga melakukan refleksi dengan guru sebagai observer. Guru dapat memberikan masukan terhadap pembelajaran yang dilakukan di siklus 1 untuk dijadikan perbaikan di siklus ke 2 .

\section{b. Siklus Lanjutan}

Apabila siklus I belum mencapai hasil yang diinginkan, maka perlu dilakukan siklus II. Memang sebenarnya untuk membuktikan efektif tidaknya PTK yang dilakukan, minimal perlu melakukan II siklus dengan tahapan seperti yang dijelaskan pada siklus I. Apabila siklus II nanti belum juga mencapai target yang diinginkan, maka perlu dilanjutkan ke siklus selanjutnya sampai hasil penelitian sesuai dengan apa yang diharapkan. Akan tetapi dalam pelaksanaannya juga memiliki batasan. Jika sampai siklus IV atau siklus $\mathrm{V}$ tetap tidak dicapai hasil yang diharapkan, maka penelitian harus dihentikan. Karena itu berarti strategi yang digunakan peneliti kurang efektif jika diterapkan pada siswa di sekolah tersebut. Peneliti perlu memikirkan strategi lain yang lebih sesuai dan akan benar-benar meningkatkan hasil belajar dan aktivitas siswa di sekolah yang akan diteliti.

Penelitian ini menggunakan pendekatan kualitatif. Pendekatan ini digunakan karena data dalam penelitian ini berupa hasil pengamatan, wawancara, hasil pemotretan, analisis dokumen, catatan lapangan, dan disusun berupa kata-kata bukan berupa angka-angka (Asmani, 2011). Teknik analisis data yang digunakan adalah teknik analisis data kualitatif yang terdiri atas tiga tahap kegiatan, yakni (1) reduksi data, (2) penyajian data dan menarik simpulan, serta (3) verifikasi data. 
Indikator keberhasilan penelitian ini, yakni (1) sekurang-kurangnya $75 \%$ siswa kelas IV SDN Sumbersari 1 Kota Malang mengalami ketuntasan belajar individual $\geq 68$. Jika hasil belajar siswa kurang dari $75 \%$ dari ketuntasan klasikal maka perlu adanya tindakan pada siklus berikutnya. Ketuntasan klasikal dikatakan berhasil apabila nilai siswa secara klasikal memenuhi standar yang ditentukan yaitu $75 \%$ (Trianto, 2010). Kriteria ketuntasan minimal satuan pendidikan SDN Sumbersari 1 Kota Malang yakni 68; (2) meningkatnya aktivitas siswa dalam pembelajaran membaca puisi dengan model demonstrasi didukung media video pembelajaran ditandai dengan aktivitas siswa minimal mendapat kriteria baik; (3) meningkatnya aktivitas guru dalam mengelola pembelajaran membaca puisi dengan model demonstrasi didukung media video pembelajaran ditandai dengan aktivitas guru minimal mendapat kriteria baik.

rumus:

Ketuntasan klasikal dihitung dengan

Ketuntasan Klasikal $=$

$\frac{\text { E siswa yang memperaleh skor } \geq 68}{\text { jumlah siswa }(25)} \times 100 \%$

Keberhasilan tindakan pada proses pembelajaran dilihat dari hasil persentase perolehan skor aktivitas guru dan siswa yang dihitung dengan rumus:

$$
\frac{\text { jumlah skor yong diperoleh }}{\text { total skor maksimal }} \times 100 \%
$$

Kemudian hasil analisis data diinterpretasikan dalam rentan keberhasilan tindakan yang ditunjukkan pada tabel berikut.

Tabel 1.1 Kategori Keberhasilan Tindakan

\begin{tabular}{ll}
\hline \multicolumn{1}{c}{$\begin{array}{c}\text { Rentang } \\
\text { Persentase }\end{array}$} & \multicolumn{1}{c}{ Kriteria } \\
\hline $76 \%-100 \%$ & Sangat Baik \\
\hline $51 \%-75 \%$ & Baik \\
\hline $26 \%-50 \%$ & Cukup \\
\hline $0 \%-25 \%$ & Kurang \\
\hline
\end{tabular}

\section{HASIL DAN PEMBAHASAN \\ Pratindakan}

Tahap pratindakan diawali dengan kegiatan pembelajaran membaca puisi di kelas IV pada tema 6 subtema 2 pembelajaran 2 . Berdasarkan hasil observasi dan wawancara yang dilaksanakan pada 16 Januari 2019 diketahui bahwa guru telah menggunakan model demonstrasi namun tidak menggunakan media pembelajaran untuk mengajarkan membaca puisi. Beberapa siswa terlihat kurang antusias ketika membaca puisi dan siswa membacakan puisi jauh dari aspek keterampilan membaca puisi yang diharapkan. Siswa membacakan puisi tanpa ada penjedaan dan intonasi seperti membaca teks bacaan. Siswa juga membaca puisi tanpa adanya ekspresi dan penghayatan. Setelah pengamatan tersebut, peneliti mewawancarai siswa dan guru tentang kendala dalam pembelajaran membaca puisi.

Permasalahan yang ditemukan pada siswa yaitu siswa tidak percaya diri dan tidak mengetahui cara membaca puisi yang baik dan benar. Disisi lain, permasalahan yang ditemukan pada guru yaitu guru tidak dapat memberikan contoh pembacaan puisi yang baik dan benar. Oleh karena itu, siswa tidak mempunyai gambaran pembacaan puisi yang baik dan benar sesuai aspek keterampilan membaca puisi. Data ketuntasan belajar membaca puisi siswa pada tahap pratindakan adalah sebagai berikut.

Tabel 1.2 Ringkasan Hasil Tes Membaca Puisi Tahap Pratindakan

\begin{tabular}{lccc}
\hline No. & $\begin{array}{c}\text { Ketuntasan } \\
\text { Belajar }\end{array}$ & Jumlah & Persentase \\
\hline 1. & Tuntas & 5 & $20 \%$ \\
\hline $2 . \quad$ Tidak tuntas & 20 & $80 \%$ \\
\hline Jumlah & 25 & $100 \%$ \\
\hline Nilai rata-rata & \multicolumn{2}{c}{$54,56 \%$} \\
\hline
\end{tabular}

Berdasarkan data pada tabel dapat diuraikan bahwa dari 25 siswa, hanya 5 siswa atau $20 \%$ dari jumlah keseluruhan siswa yang mampu membaca puisi dengan baik dan benar, sedangkan 20 siswa atau $80 \%$ siswa mengalami kesulitan dalam membaca puisi. Nilai rata-rata keterampilan membaca puisi yang diperoleh siswa sebesar 54,56\%. Dengan demikian maka secara klasikal dapat disimpulkan bahwa siswa kelas IV belum mencapai batas ketuntasan membaca puisi.

\section{Siklus I}

Pelaksanaan tindakan siklus I dilakukan pada 28 Januari 2019 pada tema 6 subtema 3 pembelajaran 4 terlaksana dengan baik, penerapan model didukung media pembelajaran dilaksanakan secara runtut dan menyeluruh. Kegiatan ini diawali dengan kegiatan pendahuluan, pada kegiatan pendahuluan guru mengucapkan salam, doa, mengecek kehadiran siswa, apersepsi, penyampaian tujuan pembejaan, rencana kegiatan, dan penilaian.

Kegiatan selanjutnya adalah kegiatan inti. Siswa membaca teks bacaan tentang kesuksesan Andrea Hirata dalam mengejar cita-cita, dari teks tersebut guru mengaitkannya pada sebuah puisi 
berjudul Laskar Pelangi. Siswa diberikan LKPD untuk menulis makna puisi tersebut. Kegiatan ini bertujuan agar siswa mampu merasakan maksud yang hendak penulis puisi sampaikan sehingga pada saat membaca puisi dapat menghayatinya. Selain itu siswa juga diminta memberikan tanda jeda dan tekanan pada puisi untuk memudahkan pembacaan. Siswa diminta membaca puisi beberapa kali hingga mampu menentukan intonasi yang tepat.

Kemudian, guru memberikan contoh pembacaan puisi. Semua siswa memperhatikan guru dengan seksama dan memberikan tepuk tangan seusai guru membacakan puisi. Selanjutnya, guru menampilkan video pembelajaran berupa pembacaan puisi oleh pemenang lomba baca puisi tingkat kabupaten/kota.

Guru memberikan penekanan pada hal yang harus diamati oleh siswa yaitu jeda, intonasi, ekspresi dan penghayatan. Semua siswa menonton video dengan antusias sambil mendiskusikan video dengan teman sebangku. Setelah itu, siswa diminta memberikan komentar atau tanggapan terhadap video yang ditampilkan.

Beberapa siswa menyampaikan pendapat mereka tentang pembacaan puisi pada video dan mampu mengapresiasinya dengan tepat, namun siswa belum memahami maksud atau isi puisi yang dibacakan disebabkan karena logat penyair puisi tersebut. Guru memberikan umpan balik terhadap respon siswa dan memberikan penguatan. Siswa diberikan waktu 5 menit untuk belajar membaca puisi di meja mereka masingmasing.

Kemudian masing-masing siswa memeragakan pembacaan puisi di depan kelas. Dalam pembacaan puisi beberapa siswa sudah mampu membacanya dengan jeda dan intonasi, namun masing sangat kurang dalam aspek ekspresi dan penghayatan. Setiap penampilan siswa diberi tanggapan oleh siswa lain untuk dijadikan perbaikan dan diberikan penghargaan berupa tepuk tangan. Setelah penampilan ke 10 guru memberikan tanggapan terhadap penampilan ke 10 siswa untuk dijadikan perbaikan ada penampilan selanjutnya.

Setelah ke 22 siswa melakukan pembacaan puisi, guru mengumumkan pembacaan puisi terbaik dengan nominasi juara 1, 2, dan 3. Hal ini dimaksudkan agar siswa termotivasi untuk meningkatkan keterampilan meraka pada pertemuan selanjutnya. Pembelajaran dilanjutkan untuk kompetensi lain.

Kegiatan setelah itu adalah kegiatan penutup. Pada kegiatan ini siswa dan guru merefleksi pembelajaran, membuat simpulan umpan balik, evaluasi, apresiasi, dan tindak lanjut. Kegiatan ditutup dengan doa dan salam.

Hasil penelitian pada siklus I dipaparkan dalam tabel berikut.

Tabel 1.3 Ringkasan Hasil Tes Membaca Puisi Siklus I

\begin{tabular}{lccc}
\hline No. & $\begin{array}{c}\text { Ketuntasan } \\
\text { Belajar }\end{array}$ & Jumlah & Persentase \\
\hline $1 . \quad$ Tuntas & 19 & $76 \%$ \\
\hline 2. $\quad$ Tidak tuntas & 6 & $24 \%$ \\
\hline Jumlah & 25 & $100 \%$ \\
\hline Nilai rata-rata & \multicolumn{2}{c}{66,45} \\
\hline
\end{tabular}

Berdasarkan data pada tabel tersebut dapat diuraikan bahwa ketuntasan belajar siswa telah mencapai $\geq 75 \%$ yakni sebesar $76 \%$ dengan nilai rata-rata kelas sebesar 66,45 . Selanjutnya dapat disimpulkan bahwa tindakan pada siklus I dianggap berhasil karena sejumlah $\geq 75 \%$ siswa tuntas belajar.

Tabel 1.4 Aktivitas Guru dan Siswa pada Siklus I

\begin{tabular}{lcc}
\hline \multicolumn{1}{c}{ Pengamatan } & Persentase & Kriteria \\
\hline Aktivitas guru & $83 \%$ & Sangat Baik \\
\hline $\begin{array}{l}\text { Aktivitas } \\
\text { siswa }\end{array}$ & $83 \%$ & Sangat Baik \\
\hline
\end{tabular}

Berdasarkan data pada tabel tersebut dapat diuraikan bahwa aktivitas guru mendapatkan persentase sebesar 83\% dengan kriteria sangat baik. Aktivitas siswa mendapatkan persentase sebesar $83 \%$ dengan kriteria sangat baik. Selanjutnya dapat disimpulkan bahwa tindakan pada siklus I dianggap berhasil karena aktivitas guru dan siswa mendapatkan kriteria sangat baik.

Temuan-temuan yang diperoleh selama kegitan pembelajaran pada siklus I dengan model Demontrasididukung media video pembelajaran (1) beberapa siswa tidak percaya diri maju di depan kelas untuk membacakan puisi dengan sukarela, sehingga guru harus menunjuk siswa tersebut; (2) hanya beberapa siswa yang aktif dalam memberikan tanggapan terhadap penampilan teman, sedangkan yang lain tidak memberikan tanggapan; (3) pada saat pembacaan puisi, siswa sudah mampu menggunakan jeda dan intonasi, namun belum mampu pada aspek ekspresi dan penghayatan.

\section{Siklus II}

Pelaksanaan tindakan siklus II dilakukan pada 30 Januari 2019 pada tema 6 subtema 3 pembelajaran 5 terlaksana dengan baik, penerapan model didukung media pembelajaran dilaksanakan secara runtut dan menyeluruh. Kegiatan ini diawali dengan kegiatan 
pendahuluan, pada kegiatan pendahuluan guru mengucapkan salam, doa, mengecek kehadiran siswa, apersepsi, penyampaian tujuan pembejaan, rencana kegiatan, dan penilaian.

Kegiatan selanjutnya adalah kegiatan inti. Perbaikan yang dilakukan dalam kegiatan inti adalah pemerataan perhatian guru kepada seluruh siswa. Siswa membaca teks bacaan yang berjudul "Meraih Cita walau Nyaris Putus Asa" kemudian siswa bertanya jawab tentang bacaan tersebut. Guru memberikan penguatan terhadap tanggapan siswa. Siswa diberikan kesempatan untuk memilih puisi yang telah dibuat sebelumnya dan berlatih membaca puisi secara mandiri dengan memperhatikan pelafalan dan intonasi.

Guru memberikan contoh pembacaan puisi, semua siswa memperhatikan pembacaan puisi oleh guru. Selanjutnya, siswa menyimak video pembacaan puisi siswa SD sebagai pemenang lomba baca puisi tingkat nasional. Semua siswa tampak antusias dan memerhatikan video dengan seksama.

Guru meminta siswa memberikan pendapat tentang pembacaan puisi dalam video tersebut sebagai bahan refleksi siswa. Siswa secara bergantian membacakan puisi di depan kelas dengan memperhatikan intonasi, lafal, jeda, dan ekspresi. Dalam pembacaan puisi mayoritas siswa sudah mampu membacanya dengan jeda, intonasi, ekspresi dan penghayatan. Setiap penampilan siswa diberi tanggapan oleh siswa lain untuk dijadikan perbaikan.

Guru menunjuk beberapa siswa yang tidak memperhatikan untuk memberikan tanggapan. Setiap penampilan siswa diapresiasi dengan memberikan tepuk tangan.

Kegiatan setelah itu adalah kegiatan penutup. Pada kegiatan ini siswa dan guru merefleksi pembelajaran, membuat simpulan umpan balik, evaluasi, apresiasi, dan tindak lanjut. Kegiatan ditutup dengan doa dan salam.

Hasil penelitian pada siklus II dipaparkan dalam tabel berikut.

Tabel 1.5 Ringkasan Hasil Tes Membaca Puisi Siklus II

\begin{tabular}{llcc}
\hline No. & $\begin{array}{c}\text { Ketuntasan } \\
\text { Belajar }\end{array}$ & Jumlah & Persentase \\
\hline $1 . \quad$ Tuntas & 24 & $96 \%$ \\
\hline 2. & Tidak tuntas & 1 & $4 \%$ \\
\hline Jumlah & 25 & $100 \%$ \\
\hline Nilai rata-rata & \multicolumn{2}{c}{78,8} \\
\hline
\end{tabular}

Berdasarkan data pada tabel tersebut dapat diuraikan bahwa ketuntasan belajar siswa telah mencapai $\geq 75 \%$ yakni sebesar $96 \%$ dengan nilai rata-rata kelas sebesar 78,8 . Selanjutnya dapat disimpulkan bahwa tindakan pada siklus II dianggap berhasil karena sejumlah $\geq 75 \%$ siswa tuntas belajar.

Tabel 1.6 Aktivitas Guru dan Siswa pada Siklus II

\begin{tabular}{lcc}
\hline \multicolumn{1}{c}{ Pengamatan } & Persentase & Kriteria \\
\hline Aktivitas guru & $86 \%$ & Sangat Baik \\
\hline $\begin{array}{l}\text { Aktivitas } \\
\text { siswa }\end{array}$ & $87 \%$ & Sangat Baik \\
\hline
\end{tabular}

Berdasarkan data pada tabel tersebut dapat diuraikan bahwa aktivitas guru mendapatkan persentase sebesar $86 \%$ dengan kriteria sangat baik. Aktivitas siswa mendapatkan persentase sebesar $87 \%$ dengan kriteria sangat baik. Selanjutnya dapat disimpulkan bahwa tindakan pada siklus II dianggap berhasil karena aktivitas guru dan siswa mendapatkan kriteria sangat baik.

Temuan-temuan yang diperoleh selama kegiatan pembelajaran pada siklus II dengan model Demontrasi didukung media video pembelajaran (1) siswa lebih aktif dalam menyempaikan komentar atau saran terhadap hasil pembacaan puisi oleh teman; (2) siswa lebih percaya diri dalam membacakan puisi; dan (3) sebagian besar siswa sudah menampakkan ekspresi serta pengahayatan saat membaca puisi.

Berdasarkan penelitian pada siklus I dan II mengalami peningkatan. Peningkatan terjadi pada keterampilan membaca puisi siswa dari rata-rata 66,45 menjadi 78,8 , jadi terjadi peningkatan sebesar 11,55. Selain itu ketuntasan belajar siswa juga meningkat dari $76 \%$ menjadi $96 \%$, jadi terjadi peningkatan sebesar $20 \%$.

Peningkatan juga terjadi pada aktivitas guru. Aktivitas guru mengalami peningkatan dari persentase $83 \%$ menjadi $86 \%$, jadi terjadi peningkatan sebesar 3\%. Pada aktivitas siswa juga mengalami peningkatan dari $83 \%$ menjadi $87 \%$, jadi terjadi peningkatan sebesar $4 \%$.

Hasil penelitian ini senada dengan riset Hanif, dkk (2018) yang menunjukkan bahwa terjadi peningkatan dari siklus I sebesar $64 \%$ menjadi $89 \%$ pada siklus II. Hal ini merupakan bukti peningkatan keterampilan membaca puisi siswa kelas V SD 1 Tritis Jepara dengan eksperimentasi model CIRC berbantuan media video pembacaan puisi.

Riset ini senada pula dengan penelitian Kusumawati dan Rochmiyati (2016) dengan hasil penelitian showed that the activity of students in prasiklus amounted to $55.6 \%$ in the category enough, the first cycle to $70.4 \%$ in both categories, and the second cycle be $80.8 \%$ in both categories. Skills to read poetry on 
prasiklus $0 \%, 52.4 \%$ in the first cycle, and the second cycle be $85.7 \%$.

\section{SIMPULAN}

Berdasarkan hasil penelitian yang dilakukan, dapat disimpulkan sebagai berikut:

1. Penerapan model pembelajaran Demontrasi didukung media video pembelajaran meningkatkan aktivitas siswa kelas IV SDN Sumbersari 1 Malang.

2. Penerapan model pembelajaran Demontrasi didukung media video pembelajaran dapat meningkatkan keterampilan membaca puisi pada siswa kelas IV SDN Sumbersari 1 Malang.

\section{DAFTAR PUSTAKA}

Arikunto, Suharsimi. 2010. Prosedur Penelitian Suatu Pendekatan Praktek. Jakarta:PT Rineka Cipta.

Asmani, Ma'mur Jamal. 2011. Tuntunan Lengkap Metodologi Praktis Penelitian Pendidikan. Jogjakarta: DIVA Pres.

Handayani, Dwi Erna. 2011. Peningkatan Keterampilan Membaca Puisi Siswa Kelas V dengan Menggunakan video Pembelajaran di SD Negeri 03 Ngadirejo Mijen Semarang. Skripsi. Semarang: Universitas Negeri Semarang.
Hanif, Laila Sajida, dkk. 2018. Peningkatan Keterampilan Membaca Puisi dengan Eksperimental Model CIRC Bermedia Video Pembacaan Puisi pada Siswa Kelas V SD 1 Tritis Jepara. Jurnal Kredo, 2 (1): 78.

Harsono, Dwi. 2016. Peningkatan Minat dan Keterampilan Membaca Puisi Siswa Kelas V SD Negeri Karangkendal I Boyolali dengan Menggunakan Media Audio Visual. Skripsi. Yogyakarta: Universitas Sanata Dharma.

Hartanti. 2015. Meningkatkan Hasil Belajar Membaca Puisi Melalui Metode Demonstrasi. Jurnal Nalar Pendidikan, 3 (2): 111-112.

Kusumawati, Fetri dan Rochmiyati, Siti. 2016. Peningkatan Keterampilan Membaca Puisi Dengan Menggunakan Teknik Pemodelan Pada Siswa Kelas III SD Negeri Mendungan 1 Kota Yogyakarta. Trihayu: Jurnal Pendidikan Ke-SD-an, 3 (1): 32-37.

Muliawan, Ungguh Jasa. 2010. Penelitian Tindakan Kelas (Classroom Action Research). Yogyakarta: Gava Media.

Santosa, Puji, dkk. 2008. Materi dan Pembelajaran Bahasa Indonesia SD. Jakarta: Univ. Terbuka.

Warsidi, Edi dan Farika. 2008. Bahasa Indonesia Membuatku Cerdas. Jakarta: Pusat Perbukuan Departemen Pendidikan Nasional. 